\title{
Global trends in maritime and port economics: the COVID-19 pandemic and beyond
}

\author{
Kevin Cullinane ${ }^{1} \cdot$ Hercules Haralambides $^{2}$
}

Accepted: 2 July 2021 / Published online: 26 July 2021

(c) The Author(s), under exclusive licence to Springer Nature Limited 2021

\section{Background}

The year 2020 will go down in history as the year of the coronavirus disease 2019 (COVID-19). With the World Health Organization's declaration of an International Pandemic on 11 March 2020, the social and economic consequences of the pandemic have spread globally as quickly as the virus itself, and in no small measure, COVID-19 has ushered in a new normal which has yet to be fathomed. Concepts such as teleworking for business, and the e-campus for education, particularly in the way they are facilitated by the simplicity of platforms such as Zoom, Teams, etc., are probably here to stay - at least to some extent and in some form. The effects of this on business travel, education and e-commerce are likely to be profound (SuauSanchez et al. 2020; Conway et al. 2020; Pokhrel \& Chhetri 2021; Mohdhar \& Shaalan 2021).

Of course, with the outbreak of the pandemic, both global production and international trade initially declined. Naturally, this had to do with the lockdown in China and the closure of many of its production facilities, and the corresponding lockdowns in Europe and North America that followed, substantially reducing the demand for Chinese imports. The Chinese lockdown, moreover, led to serious disruptions in global supply chains, demonstrating, if any more lessons were needed, the pivotal role of China as the engine of global industrial production. The shortterm economic effects of COVID-19 have been most immediately and acutely felt, however, in the contraction of global demand, mainly for merchandize goods, and the curtailing of passenger travel, holidays and entertainment activities. It should be noted, however, that the contraction in overall demand experienced over the course of the whole of 2020 has not been as dramatic as many analysts were predicting, and to the benefit of the shipping industry, the same was also true for international trade.

Kevin Cullinane

kevin.cullinane@gu.se

1 Department of Business Administration, University of Gothenburg, Gothenburg, Sweden

2 Department of Maritime Economics and Logistics, Erasmus University, Rotterdam, The Netherlands 
This has been because the contraction of demand experienced in some sectors was compensated for by an increase in demand in others, such as electronic equipment (e.g. computers and peripherals, video game consoles, etc.); mobile phones; exercise equipment; home-improvement and gardening materials; and last but by no means least, medical equipment, such as surgical masks, gowns and disinfectants, most of which have been manufactured in China. In addition, it should not be forgotten that, during the various lockdowns of the first half of the year (H1 2020), inventories were run down, as evidenced by the substantial restocking that took place in the second half of 2020 (H2 2020).

With respect to international trade specifically, this saw a decline of $4.1 \%$ in 2020 (UNCTAD 2021), but many analysts have forecast a good year in 2021. The International Monetary Fund (IMF) (2021) has forecast that the global economy will grow by $5.5 \%$ this year (1.8\% higher than 2019), on the back of faster-than-average growth amongst emerging economies. Clarksons Research (2021) suggest that global seaborne trade will surpass 2019 levels by $0.5 \%$ to reach 12 billion tonnes in 2021 , representing an annual growth rate of 4.2\%. BIMCO (2021) warns, however, that as the global economy evolves towards its 'next normal', the higher trade-GDP multiplier experienced over the pandemic will fade away, as consumer expenditure on services substitutes for goods.

\section{Impact on shipping sectors}

The COVID-19 crisis has exerted a profound impact on the shipping industry. The two shipping sectors hit the hardest were those most directly concerned with personal mobility and cross-border movements, i.e. ferry services and the cruise industry (Jenelius \& Cebecauer 2020; Urbanyi-Popiolek 2020; Renaud 2020). Ferry services and short-sea-shipping (SSS) are of great importance in two respects: (a) they provide connectivity to remote territories (e.g. small, inhabited islands) - in other words, they entail public service obligations (PSO) and are, therefore, frequently subsidized by the State concerned; and (b) they take pressure off a congested road transport system, thus reducing negative environmental externalities (see Raza et al. 2020 for a literature review of this issue). Within the European Union (EU) more specifically, SSS serves one of the top policy priorities; the Motorways of the Sea and their role not only in enticing both passenger and freight traffic from road transport, but also in connecting the transport system of the EU (Trans-European Transport Networks, TEN-T) to that of third countries, notably in Northern Africa and the Middle East (Morales-Fusco et al. 2012; Aperte \& Baird 2013; López-Navarro 2020).

It thus becomes obvious that the effects of COVID-19 on these two sectors (ferries and SSS) are far-reaching and to an extent are probably irreversible, in view of the high transaction costs associated with modal shift decisions in the case of SSS, and the EU's limited success in relieving the pressure on its road network (Sambracos \& Maniati 2020). Dry bulk and tanker shipping have also faced reduced demand and consequent hardship during the pandemic. However, given China's intense demand for commodities (e.g. iron ore and coal), dry bulk shipping is expected to do 
quite well in 2021 (Danish Ship Finance 2021). The same cannot be said for tanker shipping, a sector plagued by chronic overcapacity in an era of disinterest in fossil fuels (SSY 2021; BRS 2021). ${ }^{1}$

Realizing handsome profits overall, the one sector which did unexpectedly well in 2020 was liner (container) shipping. The market leader, Maersk Line, reported record profits for Q3 of 2020 and again in Q4. The company reported another record pre-tax profit for Q1 of 2021 that was only just below the value achieved for the whole of 2020 (Baker 2021). Anecdotal evidence suggests that North American and European shippers may be presently paying rates five to ten times more than what they would normally pay, and many of them may have to wait for weeks, if not months, to secure a slot on a ship, or find a container to bring their orders from Asia (Attinasi et al. 2021).

Judging on the basis of their shipbuilding program, it would appear that the overall positive perspective on 2021 described above is a vision shared by container carriers. As reported by Chambers (2021a), as of 5 March 2021, a total of 147 boxships have been ordered since October 2020 (most of which are in the largest size categories), compared with just 40 ships ordered in the period January to September 2020. The order book as of that date already amounted to more than 360 ships, or $12 \%$ of deployed capacity, representing a remarkable level of gross capital formation, and a leading indicator, from an industry which is rather good at adjusting its supply to demand. ${ }^{2}$ In parallel to this trend, container manufacturers in China are struggling to cope with a very high demand for container production, due to a notable worldwide shortage which is driving up freight rates and the cost of transport (Youd 2021).

Liner shipping had been quick to adjust supply to demand in H2 2020. Contrasting starkly with the current trend towards building new containerships, this was achieved with the 'withdrawal' of shipping capacity (20-30\%) from the main trade lanes, something that has come to be known as blank sailings. By October 2020, blank sailings overall during the year had reached the impressive number of 515. Port calls were thus cancelled; frequency, connectivity and quality of service declined; call sizes increased; and the volume of laid-up tonnage rose as well, reaching record levels in H1 2020; by May 2020, it amounted to $11.6 \%$ of the deployed cellular container fleet. To further reduce supply, additional measures were adopted by carriers, such as slower speeds and longer routes, via the Cape of Good Hope rather than the Suez Canal for example; in May 2020, containership transits of the Suez Canal had fallen by $32 \%$ year-on-year, to settle at an all-time low of 330 passages (BIMCO 2020).

\footnotetext{
1 The first strokes of this article were laid down in January 2021. At that time, our positive outlook for 2021 was not shared by the majority of analysts who were continuing to forecast doom and gloom. As the final lines are written in July 2021, the shipping world is again looking at the Greek tanker owners who maintain their capacity in 'ready mode' (i.e. short-term charters only), expecting a tanker boom towards the end of the year (winter). We shall therefore see if in this particular case (tanker shipping) we got our predictions right or wrong (probably the latter).

${ }^{2}$ For research on the formation of carrier expectations and the way they adjust their supply of tonnage, see Fusillo and Haralambides (2020).
} 
These actions, but particularly blank sailings, allowed carriers to sustain freight rates at impressively profitable levels. As a result, shippers and international transport associations started to publicly express their discontent over carrier behaviour during the COVID-19 crisis. Complaints were naturally addressed to the competition authorities responsible for the regulation of international shipping in the world's largest trade lanes, i.e. in the EU, USA (Federal Maritime Commission, FMC), China and Australia. The concerns expressed related to capacity management strategies; reduced levels of service; capacity withdrawals (blank sailings), lower schedule reliability; rolled containers; additional surcharges; equipment shortages, etc.

Blank sailings, coupled with a burgeoning demand for liner shipping services can easily explain the surging freight rates and carrier profits which have continued to rise at a rapid pace, hitting record levels, as reflected in movements in the value of the Drewry Composite World Container Index (WCI). In the second week of December 2020, for example, a weekly change in the WCI of 23\% (USD 793) was registered, or USD 4244 for a $40 \mathrm{ft}$. container. This was $166.6 \%$ higher than that of the same period in 2019. On 31 December, the WCI reached USD 4359, escalating to USD 5221 in the first week of 2021 (an increase of $185 \%$ year-on-year). In the same week, the annual changes in the individual freight rates reported to calculate the composite WCI for $40 \mathrm{ft}$. containers rose by $212 \%$ on Shanghai-Genoa (USD 8380); 282\% on Shanghai-Rotterdam (USD 8882); 148\% on Shanghai-New York (USD 6385); and 134\% on Shanghai-Los Angeles (USD 4194). Meanwhile, the Transatlantic route New York-Rotterdam saw an increase of 31\% (USD 690), while Rotterdam-New York decreased by 14\% (USD 2185). Price inflation continues apace in 2021; at the time of writing (at the end of H1 2021), the WCI stands at a record value of USD 8061 per forty-foot equivalent unit (FEU), representing an increase of $332 \%$ above the previous year's figure (Drewry 2021).

\section{The deus ex machina: Global Shipping Alliances}

Of course, there would be nothing wrong with the 'capacity management' strategies of carriers, ${ }^{3}$ were it not for the 'coordinated' manner in which they are implemented, amongst the members of consortia and alliances that, to a large extent, are exempted from antitrust regulation (Tang and Sun 2018). Concentration as well as vertical integration along the supply chain have been remarkable in liner shipping. ${ }^{4}$ In 1998, five alliances and three large independent shipping companies (MSC, CMA-CGM and Evergreen) co-existed. Ten years later, in 2008, the EU removed the exemption from competition law (effectively, antitrust immunity) which had been granted for years to liner shipping conferences. ${ }^{5}$ As a direct result of this, and amidst the

\footnotetext{
3 See Cariou and Guillotreau (2021) for a detailed game-theoretic analysis of capacity management strategies in the liner shipping industry.

4 Vertical integration aims at service differentiation through door-to-door transport and control of the supply chain. For a full coverage of the issue, interested readers can consult Haralambides (2019).

5 At the time, we were consulting the European Commission on the repeal of the conferences regulation. In what has come to be known as the 'Erasmus Report', we were arguing that conferences were a low-
} 
negative impacts of the financial crisis, MSC and CMA-CGM ceased to remain independent, forming a new alliance in 2009. A few years later, in 2015, Maersk and Evergreen joined their respective alliances (2M and Ocean Alliance). In this way, the process of horizontal integration through alliances evolved to the current situation, whereby the top ten shipping companies, grouped in three alliances, control more than $90 \%$ of the transoceanic container traffic. Interestingly, no large independent carrier exists at present, while in the period 2005-2016 the top ten shipping companies controlled only $60 \%$ of the total fleet capacity. As such, there is a clear rationale for questioning both the competitiveness and contestability of the market (Hirata 2017).

Although regulatory bodies, like the FMC in the USA, under pressure from shippers, have started to take a look at the causes of liner shipping profitability in the midst of a pandemic, it is unlikely that anything of substance will emerge from these inquiries. Indeed, there may be some good reasons for the leniency of the regulator: the shippers' criticisms of global shipping alliances (GSA) have failed to recognize the crucial point that unfettered competition in declining cost industries (or industries of 'increasing returns to scale') pushes prices down to marginal costs - which are always below average costs - and competition under such circumstances will then become destructive. This is the main motivation behind the (conditional) exemption of GSAs from antitrust laws, and it is exactly this same reasoning that has allowed the continued operation of price-fixing liner conferences in countries where they can still operate legitimately (mainly in and around the continent of Asia). The only difference between the two systems, alliances and conferences, is that the former primarily seek to achieve profitability through cost control, while the latter do so through price-fixing. Finally, although blank sailings have helped carriers sustain rates, this is not without costs, given that laid-up ships (or their beneficial owners) still have to pay the bank, or the K/G investors who have to absorb the losses.

\section{Impact on container ports}

Many major ports with a strong gateway function saw their container throughput plunge in H1 2020. Notable examples included Rotterdam (-7\%), Shanghai $(-6.8 \%)$, Los Angeles (-17.1\%), Hamburg (-14.7\%), Le Havre (-29\%), Barcelona $(-20.5 \%)$ and Valencia $(-9.1 \%)$. Only four major ports saw their volumes increase: Gioia Tauro $(+52.5 \%)$, Tangier Med $(+22 \%)$, Port Said-SCCT $(+23.5 \%)$ and Antwerp $(+0.4 \%) .{ }^{6}$ However, the spectacular revival of demand in H2 2020 translated immediately to increased demand for port services, with many ports reporting

\section{Footnote 5 (continued)}

cost arrangement, necessary for the survival of a 'declining costs industry'. Removing the price-setting privileges of conferences, we had argued, would lead to more concentration in terms of mergers and acquisitions (M\&As), consortia and alliances. Our alert was not heeded, unfortunately, and the outcomes are more than visible today, 20 years later.

6 Source based on data collected by the Port Authority of Valencia. 


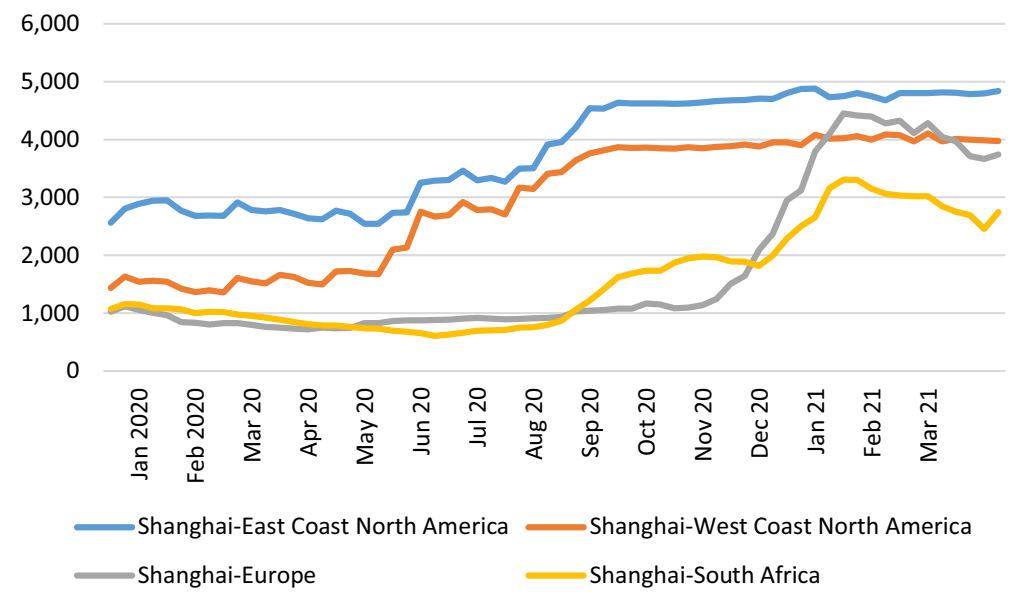

Fig. 1 Container freight rates on some major trades (USD). Note following accepted convention, the freight rates shown for Shanghai-East Coast North America (ECNA) and Shanghai-West Coast North America (WCNA) are quoted in USD per FEU, while the freight rates shown for Shanghai-Europe and Shanghai-South Africa are quoted in USD per TEU

record throughput volumes in September, October and November 2020. To a certain extent, the rise in demand related to large-scale restocking, taking place first in North America in Q3 2020, and later in Europe in Q4 2020. As an example of this, the port of Los Angeles registered a historic surge in throughput of nearly $50 \%$ in H2 2020, and in the week before Christmas the port handled 94\% more throughput than in the same week the year before (Port of Los Angeles 2021). This has been followed by another record period in Q1 2021, where throughput was $122 \%$ higher than in the previous year (Watkins 2021).

Port and transport networks were caught unprepared for such a fast transition in demand, and as a result, supply chains suffered from shortages in equipment (chassis), truck drivers and dock labour; the latter due to quarantines and constraints on personal mobility due to COVID-19. Congestion and long turnaround times have been the result, with the build-up continuing into 2021. At the time of writing, the situation has improved to some extent but, as of 1 February 2021, there were a record 40 containerships in anchorage in the San Pedro Bay area, waiting to berth at the container terminals of Los Angeles and Long Beach (Miller 2021). Congestion at these two Californian ports has been so severe that, in order to avoid becoming embroiled in it, ships have been known to offload containers, impromptu, at Oakland, $600 \mathrm{~km}$ to the north (Chambers 2021b). However, as ships are stowed with a certain ship rotation in mind, such decisions are a stowage planner's worst nightmare, and they tend to worsen the problem rather than solving it (Chou \& Fang 2021).

An important parameter that can partly explain the 'pressure' on the overall system (and the pursuant spike in container freight rates - see Fig. 1) has been the severe shortage of containers referred to earlier. Many circumstances can help explain this. First, the decline in international trade took place only in H1, with a 
precipitous fall of $12 \%$ in April-May. This, however, was reversed equally impressively in H2. The system was unable to adjust quickly to the new level of demand, with containers being left - not to say abandoned - in the 'wrong' places; with many containers having been used in H1 2020 to carry medical equipment to Africa and Latin America. In parallel with this, given the very high demand for containers in Asia, and the price that shippers would pay for them, carriers were returning empties as soon as possible, without offering Western exporters the capacity they required (Yang et al. 2021).

An additional pressure on ports was imposed by the increase in average call sizes, the intention of which was to partially compensate for blank sailings and lower frequencies. The diseconomies of scale in container ports that arise from the use of bigger ships (or bigger call sizes) have been widely recognized; for example, see Martin et al. (2015) and Haralambides (2017, 2019). At the risk of over-simplifying, one could say that the time to handle a container arriving on a large ship is on average longer than that of handling the same container arriving on a smaller ship. Even in the case of the largest ships, adding extra ship-to-shore cranes beyond more than, say, five to six makes little sense both technically and economically. Moreover, in today's container shipping context, and given contemporary containership designs, handling efficiency at berth has less to do with the number of cranes working the ship, and more to do with the availability of cranes that are able to reach row $24^{7}$ and beyond. ${ }^{8}$ Finally, competition with neighbouring ports and the requirements associated with green port status further exacerbate a terminal manager's call size headaches. Pressing things to address, jointly most of the time, include (among many others): the minimization of gate congestion; the minimization of dwell times (possibly together with the creation of dry-ports in the hinterland and the modernization of customs services); the minimization of rehandles and container-moving equipment, aiming at the same time at the minimization of atmospheric emissions; the synchronization of appointment systems with port equipment availability; the allocation of berths such that equipment movements and emissions are minimized; and incentivizing 'dual-transaction' truck movements inside the terminal.

\section{The IMO and environmental regulation}

The increasing influence of the environmental agenda on maritime business has already been alluded to. During the first few weeks of 2020, when COVID-19 had not yet been recognized as the problem it was to become, the focus of interest in the shipping industry was on the potential effect of the International Maritime Organization (IMO) 2020 global sulphur cap regulation, particularly with respect to its impact on the operational costs of ships and, thus, on the competitiveness of the shipping industry (Zis and Cullinane 2020). Considerable uncertainty existed then,

\footnotetext{
7 Rotterdam World Gateway (RWG) is already receiving the world's largest ship-to-shore container cranes (StSs), with an outreach of 26 rows, i.e. suitable for ships of 30,000 TEU.

${ }^{8}$ For a technical analysis of optimal containership design, see Priftis et al. (2018).
} 
and persists still, as to the efficacy of scrubbers (Endres et al. 2018; Comer et al. 2020; Winnes et al. 2020) and the availability of very low sulphur fuel oil (VLSFO), the price of which had reached record levels at USD 598/Metric tonnes in January 2020, as market players stockpiled compliant fuel in anticipation of (un)availability issues and even higher prices. In actuality, VLSFO prices slumped throughout 2020 (partially as the result of the previous stockpiling) and are only now recovering to their previous levels - USD 526 in Rotterdam as of 24 June 2021 (Ship \& Bunker 2021).

In terms of reducing $\mathrm{CO}_{2}$ and other greenhouse gas (GHG) emissions from shipping, the IMO has been fiercely criticized for a lack of vision and expedient progress (Shi 2016), particularly in relation to the imposition of market-based measures (Psaraftis et al. 2021). This has prompted the European Commission, within the context of its Green Deal strategy, to include shipping in the European Union's Emissions Trading system (EU ETS), irrespective of any future progress made by the IMO. This decision has caused considerable unrest in shipping industry circles, particularly amongst shipowners, and is perceived as a regional measure that undermines the merits of a multilateral approach to regulation, as advanced by the IMO.

With respect to the IMO's short-term measures for the abatement of $\mathrm{CO}_{2}$ emissions, at the meeting of its Marine Environment Protection Committee in June 2021 (MEPC 76), the IMO adopted amendments to its MARPOL Annex VI regulations, introducing two new instruments which are planned to come into force in January 2023: the Energy Efficiency Design Index for existing ships (EEXI) and the Carbon Intensity Indicator (CII). The latter effectively measures the energy efficiency of ships in relation to the transport work they undertake in moving freight and/or passengers, and this is then used to operationalize the EEXI, which is a technical instrument, directly comparable to the widely understood workings of the EEDI, but which is more generally applicable to existing ships, rather than just new ships. In the short term, it now seems that speed reductions might be the only feasible route to compliance with the new measures. Still, these new instruments have not evolved without considerable discussion and controversy, mostly raised by countries exporting perishable or time-sensitive products. The logic of their argument is that longer transit times (due to slow steaming) would impact negatively on the value of their exports (e.g. fruit or dairy products), and that the deterioration in product quality might in turn lead to modal shifts favouring air transport. Given the very high speeds of the benchmark year 2008 ( 24 knots), however, the speed reductions necessary to achieve the goals of all the short-term measures would be minimal and, as such, unlikely to lead to either product deterioration or modal shifts (Zis \& Psaraftis 2021).

\section{Future outlook: light at the end of the tunnel?}

It should be stressed that the economic hardships induced by COVID-19 were not systemic (as was the case with the global financial crisis of 2009) but, rather, the result of an unforeseen external shock. As such, it is to be hoped that, with expedient progress in vaccinations, as seems to be the case at the time of writing, the 
world economy will not only return to pre-COVID-19 levels of activity but will, in all probability, surpass them. As has been described earlier, economic forecasts are generally positive in this respect, and evidence of this can be observed in the way that China has already started its steady upward path, with a remarkable Q4 2020 growth rate of $6.5 \%$. This brought the country's overall annual growth rate to $2.3 \%$, thus correcting a Q1 2020 contraction of $6.8 \%$ (National Bureau of Statistics of China 2021).

One cause for future (economic) concern is the astronomical amount of money earmarked around the world in the fight against COVID-19, especially for mitigating its effects on employment. Within the EU, the level of spending involved has literally rendered completely invalid the limits on public spending and budget deficits embodied within the EU's Stability Pact. On the positive side, however, the financing of the EU's Recovery Fund [what has come to be known as the New Generation EU (NGEU)] through the issuance of mutual debt, and the future payback of this debt through direct taxation, represents the first solid step towards the fiscal integration of the EU that might guarantee its long-term survival (Acharya $\&$ Steffen 2017). The lion's share of the recovery fund will go to Europe's weaker economies (Bulgaria, Romania, Greece, Croatia, etc.), as well as to those hit the hardest by the pandemic (Italy and Spain). On the negative side, it must be said, the Commission's attempts to 'condition' the spending of recovery funding on what it considers to be necessary economic reforms and the 'rule of law' have been rather unsuccessful, with certain member states questioning the legitimacy of linking 'life and health' issues with conditions and considerations related to economic performance and political governance (Fuest 2021).

With the 2020 election of Joe Biden as president of the USA, the world is now seeking a real commitment to reversing the introversion and isolationism which characterized the Trump administration. Although Biden is no great proponent of the free trade ethos, in seeking to distance himself from the political and policy idiosyncrasies of his predecessor, he is likely to try and restore better relations with both China and the EU (the world is already seeing evidence of this) and to re-engage the USA with a multilateralist approach to trade relations and other international issues (Cullinane 2020). Such a change in approach has been manifest in the representation of the USA within the IMO where, remarkably, the USA is now, volte-face, a stalwart of the environmental agenda, in vociferous pursuit of much more stringent measures to secure the best possible environmental performance from the international shipping industry.

Finally, it has to be recognized that, throughout Europe and the USA, concepts such as localization, near-shoring, 3-D printing, teleworking and the like have been finding fertile ground among the populace. Even under the new Biden administration in the USA, for example, there are clear and explicit, yet very ambitious, objectives for the re-shoring of production and associated supply chains, motivated not only by the need (exposed by the COVID-19 pandemic) to reduce the risks associated with supply chain vulnerabilities, but also by the explicit and understandable desire to benefit workers in the USA. If these sensibilities and tendencies are replicated worldwide and if this were to emerge as the new normal (i.e. if a reduction in trading distances becomes a possibility), then 
the negative impacts on the transportation industries, starting from long-distance business-class travel and progressing then to international shipping, are only too obvious.

Acknowledgements The authors are grateful to Manuel José García Navarro of the port of Valencia for research and general support.

\section{References}

Acharya, V.V., and S. Steffen. 2017. The importance of a banking union and fiscal union for a capital markets union. Fellowship Initiative "Challenges to Integrated Markets" Discussion Paper No. 062. July. Luxembourg: Publications Office of the European Union. https://ec.europa.eu/info/sites/defau 1t/files/dp_062_en.pdf.

Aperte, X.G., and A.J. Baird. 2013. Motorways of the sea policy in Europe. Maritime Policy and Management 40 (1): 10-26.

Attinasi, M.G., A. Bobasu, and R. Gerinovics. 2021. What is driving the recent surge in shipping costs? ECB Economic Bulletin, Issue 3/2021. https://www.ecb.europa.eu/pub/economic-bulletin/focus/ 2021/html/ecb.ebbox202103_01 8ecbf2b17c.en.html.

Baker, J. 2021. Maersk posts record first-quarter earnings. Lloyd's List, 5 May. https://lloydslist.marit imeintelligence.informa.com/LL1136670/Maersk-posts-record-first-quarter-earnings.

BIMCO. 2020. Suez Canal ship transits rise amidst the COVID-19 pandemic, 16 June. https://www. bimco.org/news/market_analysis/2020/20200616_suez_canal_ship_transits.

BIMCO. 2021. Macroeconomics: Shipping enjoys a higher trade multiplier as 2021 promises a slow recovery. https://www.bimco.org/news/market_analysis/2021/20210224_macroeconomics.

BRS. 2021. Annual review of shipping and shipbuilding. Paris: BRS Group. https://www.brsbrokers.com/ assets/review_splits/BRS_Review_2021_Tanker.pdf.

Cariou, P., and P. Guillotreau. 2021. Capacity management by global shipping alliances: Findings from a game experiment. Maritime Economics and Logistics. https://doi.org/10.1057/s41278-021-00184-9.

Chambers, S. 2021a. Ordering spree shuffles liner rankings. Splash247.com, 16 March. https://splash247. com/ordering-spree-shuffles-liner-rankings/.

Chambers, S. 2021b. Californian port congestion spreads north to Oakland. Splash247.com, 4 February. https://splash247.com/californian-port-congestion-spreads-north-to-oakland/.

Chou, C.C., and P.Y. Fang. 2021. Applying expert knowledge to containership stowage planning: An empirical study. Maritime Economics and Logistics 23 (1): 4-27.

Clarksons Research. 2021. Shipping Intelligence Weekly, 6 March. London: Clarksons Shipbrokers.

Comer, B., E. Georgeff, and L. Osipova. 2020. Air emissions and water pollution discharges from ships with scrubbers. ICCT Consulting Report. Washington, DC: International Council on Clean Transportation. https://theicct.org/sites/default/files/publications/Air-water-pollution-scrubbers-nov2020. pdf.

Conway, M.W., D. Salon, D.C. da Silva, and L. Mirtich. 2020. How will the COVID-19 pandemic affect the future of urban life? Early evidence from highly-educated respondents in the United States. Urban Science 4 (4): 50.

Cullinane, K.P.B. 2020. The impact of the US presidential election on logistics. In Stjärnspäckat - reflektioner från amerikanska presidentvalet 2020 av ledande forskare, ed. Bolin, N., K. Falasca, M. Grusell, and L. Nord, 87. Sundsvall: Mittuniversitetet, DEMICOM. https://www.stjarnspackat.se/ globalassets/ovrigt/stjarnspackat/stjarnspackat_demicomrapport-43_v2.pdf.

Danish Ship Finance. 2021. Shipping market review, May 2021. https://www.shipfinance.dk/media/2098/ shipping-market-review-may-2021.pdf.

Drewry. 2021. World container index. London: Drewry Shipping Consultants Ltd. https://www.drewry. co.uk/supply-chain-advisors/supply-chain-expertise/world-container-index-assessed-by-drewry.

Endres, S., F. Maes, F. Hopkins, K. Houghton, E.M. Mårtensson, J. Oeffner, et al. 2018. A new perspective at the ship-air-sea-interface: The environmental impacts of exhaust gas scrubber discharge. Frontiers in Marine Science 5: 139. 
Fuest, C. 2021. The NGEU economic recovery fund. Cesifo Forum 22 (01): 03-08.

Fusillo, M., and H. Haralambides. 2020. Do carrier expectations indicate industry structure in container shipping? An econometric analysis. Journal of Shipping and Trade 5 (1): 1-16. https://doi.org/10. 1186/s41072-019-0057-2.

Haralambides, H. 2017. Globalization, public sector reform, and the role of ports in international supply chains. Maritime Economics and Logistics 19 (1): 1-51.

Haralambides, H. 2019. Gigantism in container shipping, ports and global logistics: A time-lapse into the future. Maritime Economics and Logistics 21 (1): 1-60.

Hirata, E. 2017. Contestability of container liner shipping market in alliance era. The Asian Journal of Shipping and Logistics 33 (1): 27-32.

IMF. 2021. World Economic Outlook update. Washington, DC: International Monetary Fund. https:// documentcloud.adobe.com/link/review? uri=urn:aaid:scds:US:4a6d74db-f2b9-4fae-b173-0a52b $3694 \mathrm{~d} 16$.

Jenelius, E., and M. Cebecauer. 2020. Impacts of COVID-19 on public transport ridership in Sweden: Analysis of ticket validations, sales and passenger counts. Transportation Research Interdisciplinary Perspectives 8: 100242.

López-Navarro, M.A. 2020. Ro-Ro short sea shipping and Motorways of the Sea. In Short sea shipping in the age of sustainable development and information technology, ed. T.A. Santos and C.G. Soares, 183-198. Abingdon: Routledge.

Martin, J., S. Martin, and S. Pettit. 2015. Container ship size and the implications on port call workload. International Journal of Shipping and Transport Logistics 7 (5): 553-569.

Miller, G. 2021. New video shows massive scope of California boxship traffic jam. American Shipper, 11 February. https://www.freightwaves.com/news/new-video-shows-massive-scope-of-california-boxship-traffic-jam.

Mohdhar, A., and K. Shaalan. 2021. The future of e-commerce systems: 2030 and beyond. Recent Advances in Technology Acceptance Models and Theories 335: 311-330.

Morales-Fusco, P., S. Saurí, and A. Lago. 2012. Potential freight distribution improvements using motorways of the sea. Journal of Transport Geography 24: 1-11.

National Bureau of Statistics of China. 2021. Preliminary accounting results of GDP for the fourth quarter and the whole year of 2020. http://www.stats.gov.cn/english/PressRelease/202101/t20210120_ 1812680.html.

Pokhrel, S., and R. Chhetri. 2021. A literature review on impact of COVID-19 pandemic on teaching and learning. Higher Education for the Future 8 (1): 133-141.

Port of Los Angeles. 2021. Port of Los Angeles reaches 9.2 million TEUs in 2020. Port of Los Angeles Authority, 14 January. https://www.portoflosangeles.org/references/2021-news-releases/news_ 011421_sotp2021.

Priftis, A., E. Boulougouris, O. Turan, and A. Papanikolaou. 2018. Parametric design and multi-objective optimisation of containerships. Ocean Engineering 156: 347-357.

Psaraftis, H.N., T. Zis, and S. Lagouvardou. 2021. A comparative evaluation of market-based measures for shipping decarbonization. Maritime Transport Research 2: 100019.

Raza, Z., M. Svanberg, and B. Wiegmans. 2020. Modal shift from road haulage to short sea shipping: A systematic literature review and research directions. Transport Reviews 40 (3): 382-406.

Renaud, L. 2020. Reconsidering global mobility-Distancing from mass cruise tourism in the aftermath of COVID-19. Tourism Geographies 22 (3): 679-689.

Sambracos, E., and M. Maniati. 2020. 10 The cost of modal shift. In Short sea shipping in the age of sustainable development and information technology, ed. T.A. Santos and C.G. Soares, 224-241. Abingdon: Routledge.

Shi, Y. 2016. Reducing greenhouse gas emissions from international shipping: Is it time to consider market-based measures? Marine Policy 64: 123-134.

Ship \& Bunker. 2021. Rotterdam bunker prices. https://shipandbunker.com/prices/emea/nwe/nl-rtm-rotte rdam.

SSY. 2021. Outlook 2021. London: Simpson, Spence \& Young. https://www.ssyonline.com/media/1907/ ssy-2021-outlook-report.pdf.

Suau-Sanchez, P., A. Voltes-Dorta, and N. Cugueró-Escofet. 2020. An early assessment of the impact of COVID-19 on air transport: Just another crisis or the end of aviation as we know it? Journal of Transport Geography. https://doi.org/10.1016/j.jtrangeo.2020.102749.

Tang, O., and P.W. Sun. 2018. Anti-competition of ocean shipping alliances: A legal perspective. Maritime Business Review 3 (1): 4-19. 
UNCTAD. 2020. Review of maritime transport 2020. New York: United Nations Conference on Trade and Development, United Nations Publications.

Urbanyi-Popiolek, I. 2020. Maritime tourism in the time of COVID-19 pandemic in the Baltic Sea region-Challenges for ferry and cruise operators. In Economic and social development: Book of proceedings, 397-405.

Watkins, E. 2021. Port of Los Angeles eyes record throughput. Lloyd's List, 28 May. https://lloydslist. maritimeintelligence.informa.com/LL1136938/Port-of-Los-Angeles-eyes-record-throughput.

Winnes, H., E. Fridell, and J. Moldanová. 2020. Effects of marine exhaust gas scrubbers on gas and particle emissions. Journal of Marine Science and Engineering 8 (4): 299.

Yang, R., M. Yu, C.Y. Lee, and Y. Du. 2021. Contracting in ocean transportation with empty container repositioning under asymmetric information. Transportation Research Part e: Logistics and Transportation Review 145: 102173.

Youd, F. 2021. Global shipping container shortage: The story so far. Ship Technology, 29 April. https:// www.ship-technology.com/features/global-shipping-container-shortage-the-story-so-far/.

Zis, T.P.V., and K.P.B. Cullinane. 2020. The desulphurisation of shipping: Past, present and the future under a global cap. Transportation Research d: Transport and Environment 82: 102316.

Zis, T.P.V., and H.N. Psaraftis. 2021. Impacts of short-term measures to decarbonize maritime transport on perishable cargoes. Maritime Economics and Logistics. https://doi.org/10.1057/ s41278-021-00194-7.

Publisher's Note Springer Nature remains neutral with regard to jurisdictional claims in published maps and institutional affiliations. 